\title{
Effect of Sparring Training Model on Liver Enzymes and Muscle Damage in Boxers
}

\author{
Ömer Kaynar \\ Correspondence: Ömer Kaynar, School Of Physical Education and Sports, Muş Alparslan University, Turkey.
}

Received: February 2, 2019

doi:10.11114/jets.v7i3S.4152

Accepted: March 15, $2019 \quad$ Online Published: March 19, 2019

URL: https://doi.org/10.11114/jets.v7i3S.4152

\begin{abstract}
The purpose of this study is to examine the acute effect of sparring training model on liver enzymes and muscle damage in boxers. 14 voluntary athletes engaged in box $(23.71 \pm 1.44$ years of age; $167 \pm 5.89 \mathrm{~cm} ; 62.05 \pm 8.89 \mathrm{~kg})$ participated in the study. Sparring training model composed of warm-up (25 minutes), main part (30 minutes) and cool-down (15 minutes) exercises was applied to the boxers. The main theme of the study is composed of the free sub-stroke sparring training model in the liver region. Sparring training applied in the liver region and consisting of 3-minute time periods was repeated 3 times with a 1-minute interval as in the punch bag training. In venous blood samples taken from the study group before and after sparring training, AST, ALT and GGT enzyme activities and CK and LDH levels were analyzed with the spectrophotometric method in Beckman Coulter AU 5800 auto analyzer. Data were analyzed in SPSS 22.0 package program. The significance level was accepted as $p<0.05$ in statistical evaluations. Normal distribution of data was determined with Shapiro-Wilk test. Paired t-test was used in the statistical analysis of normally distributed data. Comparing AST, ALT, GGT, LDH and CK values of boxers before and after the training, it has been observed that there is a significant increase in AST, LDH and CK values after the training $(\mathrm{p}<0.05)$ and significant decrease in GGT values $(\mathrm{p}<0.05)$ while there is no significant difference in ALT values $(\mathrm{p}>0.05)$. In conclusion, it has been determined that sparring training model applied to boxers affects liver enzyme levels in them and significant increases occur in CK and LDH. More comprehensive prospective studies are required in order to establish the possible damage of punches to the liver region on liver in boxers.
\end{abstract}

Keywords: sparring training, liver enzymes, muscle damage, boxers

\section{Introduction}

Boxing is a martial art with two distinct styles namely amateur and professional in which two people wearing gloves fight with each other with blows according to certain rules El-Ashker S, \& Nasr M (2012).This sports, which has millions of spectators, increases its popularity day by day because of its high taste of watching. In contrast, boxers receive punch strokes in their heads or liver areas during training and in competitions. It is known that these blows reveal a wide spectrum of causes from various fractures, injuries, permanent injuries, and even to deaths due to their acute or chronic effects (Kelestimur et al 2004; Zazryn TR, Finch CF, McCrory PA,2003; 3Kraemer WJ, Ratamess NA. 2005).

Boxers have often had to quit training or competition because of these strokes. This situation affects the general health status of the boxers and accordingly affects their sports performance negatively (Tanriverdi et al, 2007; Kaynar, Erbay and Gültekin, 2007). In fact, it has been reported that there are cases of death in boxers due to liver failure arising from the chronic effect of the punches in the liver area (Sinan Şamil Şam Neden Öldü, 2019)

Alanine amino transferase (ALT), aspartate aminotransferase (AST), alkaline phosphatase (ALP) and gamma glutamyl transpeptidase (GGT) are the enzymes commonly used in the detection of liver damage (Karaciğer Enzimleri, 2003; Brooks, Fahey, Baldwin, 1995). Exercise is known to cause muscle damage at different levels. Muscle injury is a condition that causes muscular exhaustion, loss of function, weakness and pain after unusual and severe exercises. Creatine kinase (CK) and lactate dehydrogenase (LDH) are considered to be a specific indicator of muscle damage destruction. It has been reported in many studies that high-intensity exercises increase liver enzyme levels and muscle damage (Chevion, Moran and Heled, 2003; Hazar, 2004).

Especially after heavy and strenuous exercises requiring high strength, AST and ALT elevates in liver and CK and LDH levels elevate in blood (Amat et al.2007; Kraemer, Kilgore, Kraemer and Castracane,1992; Nathwani, Pais, Reynolds 
\& Kaplowitz,2005). In the literature studies, many biochemical parameters about liver enzymes and muscle damage before and after training were investigated in boxers (Ayhan et al. 2017; Trrabass1, Lucianne, Morteza, 2018; Baygultalp et al 2016).

However, no studies have been found to investigate the acute effect of punch strokes thrown at a specific time and intensity to the liver region. However, what the impact of a series of punch strokes in the liver area in a short period of time can cause on the liver and how these punch strokes can cause damage to the liver in the following years is very important in terms of the health and performance of athletes.

For this reason, this first study in literature aims to investigate the acute effect of sparring training model which is specific to liver region on liver enzymes and muscle damage in boxers.

\section{Methods}

\section{Research Ethics Committee Report}

This study was carried out with the research group below after taking the consent of the participants and approval of the Scientific Research Ethics Committee of Atatürk University Faculty of Medicine dated 04.10.2018 and numbered B.30.2.ATA.0.01.00 / 279 .

\section{Research Group}

The research group is composed of 14 voluntary boxers doing sports actively. Through the Informed Consent Form (ICF), the volunteers of the study were informed about the content of sparring training model verbally and in written. The study was initiated after taking the approval of volunteers.

\section{Exercise Protocol}

\section{Sparring Training Protocol}

Sparring training protocol is composed of warm up (start), main part and cool down (finish) sections.

Warm up (start) (25 minutes): In the first and last 5 minutes of the warm-up section, the participant boxers were requested to perform aerobic running at 50\% intensity. Between runs, the participant boxers were applied isometric, isotonic, mobility and stretching exercises for the lower and upper extremities, waist and neck region and joints and muscle groups in order to minimize the risk of possible injuries to occur in the main part of the training session in boxers (Baltimore, Williams and Wilkins, 2005; Pollock, Gaesser, Butcher,1998; Coyle et al,1984) and double, triple and quadruple combined fist exercises in front of the mirror in accordance with the theme to be applied in the main section.

Main part (30 minutes): The exercise of punching the bag composed of 3-minute time periods was applied 3 times and 1-minute rest was allowed between each of 3-minute exercises. 8-minute of active rest was allowed after punching the heavy bag. During the active rest period, boxers were matched by age and weight categories. Following the rest, a free sub-stroke sparring training method was applied to the liver region, which constitutes the main theme of this study. Sparring training in the liver region consisting of 3-minute time periods was repeated 3 times with a 1-minute interval as in the punching bag study.

Cool down (finish) (5 minutes): In the last part of the training, the movements in the warm-up section for the joint and muscle groups, mostly stretching practices were made after the aerobic running at $40 \%$ intensity for 5 minutes.

\section{Taking the Blood Samples from Athletes and Biochemical Analysis}

Blood samples were taken from antecubital region twice before and after the training in order to determine the liver enzymes (AST, ALT and GGT) and muscle damage (CK and LDH) values from the study group. After the first sample was taken by professionals from the athletes in a sitting position after allowing 5-minute rest before the exercise, the second sample was taken into the biochemistry tube after the main part of the training. Blood samples were centrifuged at $3000 \mathrm{rpm}$ for 10 minutes to separate serum. In serum samples, the liver enzymes of ALP, AST, ALT and GGT were analyzed with spectrophotometric method in Beckman Coulter, AU 5800 analyzer. CK and LDH enzyme activities of centrifuged blood were measured with calorimetric method in Roche elecsys E-170 device by using a Roche brand commercial kit.

\section{Statistical Analysis}

Data were analyzed by using SPSS 22.0 package program. The significance level was accepted as $\mathrm{p}<0.05$ in statistical evaluations. Shapiro-Wilk test was used to determine the normal distribution of data. Paired t-test was used in the statistical analysis of normally distributed data. 


\section{Results}

Table 1 shows the information about the sports duration of boxers with the mean scores of $17.86 \pm 5.60$ age (years), $173.64 \pm 10.08$ height $(\mathrm{cm})$ and $63.86 \pm 11.57$ weight $(\mathrm{kg})$.

Table 1. Demographic characteristics of boxers

\begin{tabular}{lccc}
\hline Physical attribute & [Mean \pm sd ] & Duration of doing sports [14(100\%)] \\
\hline Age (year) & $17.86 \pm 5.60$ & $1-4$ Years & $5(35.71 \%)$ \\
Height $(\mathbf{c m})$ & $173.64 \pm 10.08$ & $5-8$ Years & $4(28.58 \%)$ \\
Weight $(\mathbf{k g})$ & $63.86 \pm 11.57$ & $9+$ & $5(35.71 \%)$ \\
BMI $\left(\mathbf{k g} / \mathbf{m}^{2}\right)$ & $21.08 \pm 2.54$ & & \\
\hline
\end{tabular}

Table 2. AST, ALT, GGT, LDH and CK values of boxers

\begin{tabular}{llccc}
\hline \multicolumn{1}{c}{ Before Training } & After Training & & \\
\hline Parameters & \multicolumn{1}{c}{$(\overline{\mathrm{x}} \pm \mathrm{SS})$} & $(\overline{\mathrm{x}} \pm \mathrm{SS})$ & $\mathbf{t}$ & $\mathbf{p}$ \\
AST(U/L) & $23.21 \pm 4.14$ & $25.86 \pm 4.69$ & -2.082 & $0.048^{*}$ \\
ALT(U/L H) & $14.93 \pm 3.83$ & $13.79 \pm 4.82$ & 1.228 & 0.241 \\
GGT(U/L H) & $11.21 \pm 3.29$ & $9.43 \pm 3.32$ & 3.051 & $0.009^{*}$ \\
LDH (U/L) & $222.21 \pm 36.00$ & $287.00 \pm 61.30$ & -3.266 & $0.006^{*}$ \\
CK(U/L) & $242.14 \pm 183.55$ & $332.14 \pm 198.36$ & -3.570 & $0.003^{*}$ \\
\hline
\end{tabular}

AST $=$ Aspartate Aminotransferase, ALT= Alanine Aminotransferase, GGT= Gama Glutamyl Transferase.

$\mathrm{LDH}=$ Lactate dehydrogenase, $\mathrm{CK}=$ Creatine Kinase

Comparing the AST, ALT, GGT, LDH and CK values of boxers before and after the training in the findings of the study, it has been determined that there is a significant increase in the values of AST, LDH and CK $(p<0.05)$, there is a significant decrease in GGT values $(p<0.05)$ and there is no significant difference in ALT values $(p>0.05)$.

\section{Discussion}

AST, ALT and GGT are the biochemical markers used in ascertaining liver damage and LDH and CK are frequently used to determine the damage in the muscle (Gomez-Cabrera et al, 2008; Brown,Day and Donelly,1999) Liver enzymes and muscle damage vary according to the type, duration and severity of exercise (Farrell, Garthwaite, Gustafson, 1983; Hyatt J PK, Clarkson,1998).

The findings of our study indicate that there is a significant increase in AST, LDH and CK values after the sparring training in boxers $(\mathrm{P}<0.05)$, there is a significant decrease in GGT values $(\mathrm{P}<0.05)$ and no significant difference exists in ALT values $(\mathrm{P}<0.05)$.

An increase in intensity and duration of exercise is known to elevate ALT and AST levels in general terms, Rosmarın, (Beard and Robbins, 1993).

An increase has been observed in GGT and AST values after the competition in athletes running marathon while GGT values have decreased 6 hours after the competition and AST values have increased even after 24 hours (Çakmakçı and Pulur, 2008). A significant increase has been ascertained in AST and ALT levels of professional cyclists after $234 \mathrm{~km}$ of race (Mena, Maynar, Campillo,1996), liver enzymes have been elevated after the intense training in long-distance runners (Morris, Nevill and Williams,2004) and weightlifters (Paolisso, Giuseppe, et al ,1997) compared to pre-training period.

It has been reported in many studies that heavy and strenuous exercises increase liver enzyme levels and muscle damage. In the study of (Özkan et al, 2014) performed on wrestlers, a significant increase has been stated in CK and LDH enzyme activities while AST and ALT values don't differ significantly. In a similar study analyzing the exercise dependent muscle damage, a significant increase has been found in CK, LDH, AST and ALT enzyme activities (Clarkson, 2006).

In the study of Kaynar et al (2016), kickboxers have done a training match for 2 minutes equivalent to a kickbox match 
composed of 3 sets (1-minute rest in half-time) after they have been applied 40 minutes of warm-up exercises, stretching movements and 50 minutes of technical and tactical training. Afterwards, it was stated that there was a significant increase in AST, ALT, ALP and GGT values after the training and this increase may be caused by the effects of punches or kicks to the abdominal region during the match on liver region. In another study by Kaynar (2018), a significant increase has been recorded in AST and ALP values but no significant difference has been stated in ALT and GGT values after a 3-minute training match equivalent to a wrestling match composed of 2 sets $(30$ sec. rest in half-time) following 30 minutes of mild running, warm-up and gymnastic movements and 25 minutes of technical practices of wrestling applied to wrestlers (Kaynar, 2018). They have argued that wrestlers' falling sharply on the ground during training or competition and the pressure applied on the abdomen in the "gut wrench technique" might cause elevation of liver enzymes.

In a study conducted on elite volleyball players, LDH plasma levels have been stated to significantly increase after training when comparing pre and post-training values Ji-Qing (2013). In a study performed on distance runners, blood samples taken before $3000 \mathrm{~m}$ test running and after 1.4 and 24 hours have been compared. LDH and GGT have been found to be significantly elevated 1 hour after the $3000 \mathrm{~m}$ test run and AST and ALT levels have significantly increased after 4 hours. All parameters have been observed to fall to the pre-exercise levels 24 hours after the test (Güreş, 2009).

The fact that the damage in liver and muscle differs by the type and intensity of the exercise done [10] shows similarity with the findings of our study. In fact, it is thought that both AST, ALT and CK and LDH enzymes increase in muscle and liver not because of the attributes of exercise but due to the fact that punches to the liver region cause muscle and liver damage and as a result, enzyme activities elevate as understood from the kickbox athletes Kaynar et al (2016), and wrestlers (Kaynar, 2018).

As a result of the sparring training program applied to the boxers, it has been observed that liver enzyme levels are affected and CK and LDH being a marker of muscle damage significantly increase. More extensive prospective studies are required in order to detect the damage caused by punches to the liver region in the liver.

\section{References}

8.Karaciğer Enzimleri http://saglikdanisma.net/hastaliklar/ diger/sozluk-2/karaciger-enzimleri.html 24.12.2013.

Amat, A. M., Corrales, J. A. M., Serrano, F. R., Boulaiz, H., Salazar, J. C. P., \& Contreras, F. H., et al. (2007). Role of -actin in muscle damage of injured athletes in comparison with traditional markers, British Journal of Sports Medicine, 41, 442-446. https://doi.org/10.1136/bjsm.2006.032730

Ayhan, S., Ersöz, G., Güllü, A., Akpolat, V., \& Tizar, E. (2017). The Effects of Competition Performance in Elite Male Football Players on Selected Biochemical and Hematological Parameters. International Archives of Medical Research, 9(1), 15-23. dergipark.gov.tr/iamr/issue/42437/511260

Baltimore (MD). (2005). Williams and Wilkins; ACSM's guidelines for exercise testing and prescription American College of Sports Medicine.7 th ed. 2005. https://www.acsm.org/read-research/books/acsms-guidelines-for-exercise-testing-and-prescription.

Baygutalp, N. K., Ozturk, N., Bakan, E., Kurt, N., Mehmet, A. G., Dorman, E., \& Yazici, A. G. (2016). Acute effects of training on some biochemical analytes in professional boxers sub-title: Biochemical analytes in boxers. International Journal, 4(1), 39-52. https://doi.org/10.15640/ijmp.v4n1a2

Brooks, G. A., Fahey, T. D., \& Baldwin, K. M. (1995). Exercise Physiology, Human Bioenergetics and Its Applications, Fourth Edition, McGraw-Hill Companies, New York, 1995. https://www.amazon.com/Exercise-Physiology-Human-Bioenergetics.

Brown, S., Day, S., \& Donelly, A. (1999). Indirect Evidence of Human Skeletal Muscle Damage and Collogen Breakdown after Eccentric Muscle Action. J Sport Science, 17(5), 397-402. https://doi.org/10.1080/026404199365911

Çakmakçı, E., \& Pulur, A. (2008). Milli Takım Kamp Döneminin Bayan Taekwondocularda Bazı Biyokimyasal Parametreler Üzerine Etkileri. S.Ü. Bes Bilim Dergisi, 10, 39-47. https://doi.org/10.1136/bjsm.30.2.122

Chevion, S., Moran, D., \& Heled, Y. (2003). Plasma antioxidant status and cell injury after severe physical exercise. Proceedings of the National Academy of Sciences, 100(5), 119-5123. https://doi.org/10.1073/pnas.0831097100

Clarkson, P. M., Kearns, A. K., Rouzier, P., Rubin, R., \& Thompson, P. D. (2006). Serum creatine kinase levels and renal function measures in exertional muscle damage. Medicine and Science in Sports and Exercise, 38(4), 623. https://doi.org/10.1249/01.mss.0000210192.49210.fc

Coyle, E. F., Martin, W. H., Sinacore, D. R., Joyner, M. J., Hagberg, J. M., \& Holloszy, J. O. (1984). Time course of loss 
of adaptations after stopping prolonged intense endurance training. J Appl Physiol., 57, 1857-1864. https://doi.org/10.1152/jappl.1984.57.6.1857

El-Ashker, S., \& Nasr, M. (2012). Effect of boxing exercises on physiological and biochemical responses of Egyptian elite boxers. Journal of Physical Education and Sport, 12(1), 111. https://efsupit.ro/images/stories/nr\%201\%202012/vol\%2012_1_\%20art\%2018

Farrell, P. A., Garthwatte, T. L., \& Gustafson, A. B. (1983). Plasma Adrenokorticotropin and Cortisol Responses to submaximal and Exhaustive Exercise. Journal of Applied Physiology, 55(5), 1441-1444. https://doi.org/10.1152/jappl.1983.55.5.1441

Gomez-Cabrera, M C., Domenech, E., \& Romagnoli, M, et al. (2008). Oral administration of vitamin C decreases muscle mitochondrial biogenesis and hampers training-induced adaptations in endurance performance. Am J Clin Nutr., 87, 142-149. https://doi.org/10.1093/ajcn/87.1.142

Güreş, A., Karul, A., Kozacı, D., Gürel, G., \& Güreş, Ş. (2009). Mesafe Koşucularında Submaksimal Egzersizin Kan Biyokimyasına Etkisi, Spor Hekimliği Dergisi, 44, 89-95. https://www.sporhekimligidergisi.org/tam-metin-pdf/103/tur

Hazar, S., Egzersize, B. İ., \& Kalp, K. H. (2004). SPORMETRE Beden Eğitimi ve Spor Bilimleri Dergisi. 2(3), 119-126. http://dergiler.ankara.edu.tr/dergiler/17/895/11212.pdf

Hyatt, J. P. K. (1998). Clarkson PM Creatin Kinase release and clearence using MM variants following repeated bouts of eccentric exercise. Medicine and Science in Sport and Exercise, 30(7), 1059-1065. https://www.ncbi.nlm.nih.gov/pubmed/9662673

Işık, Ö., Alpay, C. B., Hazar, S., \& Eker, H. (2014). A study examining the effects of changed rules of wrestling competitions on the muscular damage levels of the elite wrestlers. Turkish journal of Sport and exercise, 16(1), 18-24. http://dergipark.gov.tr/download/article-file/200676

Ji-Qing, X., Yang, Z., Wei, F., Ai-Qing, H., Shang-Bin, L., Shu-Hong, L., \& Li-Min, R. (2013). The effect of pre-competition training on biochemical indices and immune function of volleyball players. Int J Clin Exp Med., 6(8), 712-715. https://www.ncbi.nlm.nih.gov/pubmed/24040482

Kaynar, Ö., Erbay, Ü. Z., \& Gültekin, M. (2017). Pseudotumor Cerebri in a Retired Boxer. Erciyes Med J., 39(3), 143-145. https://doi.org/10.5152/etd.2017.17075

Kaynar, Ö., Öztürk, N., Kıyıcı, F., Baygutalp, N. K., \& Bakan, E. (2016). The Effects of Short-Term Intensive Exercise on Levels of Liver Enzymes and Serum Lipids in Kick Boxing Athletes. Dicle Medical Journal, 43(1), 130-134. https://doi.org/10.5798/diclemedj.0921.2016.01.0652

Kelestimur, F., Tanriverdi, F., Atmaca, H., Unluhizarci, K., Selcuklu, A., \& Casanueva, F. F. (2004). Boxing as a sport activity associated with isolated GH Deficiency. Journal of Endocrinological Investigation, 27, 28-32. https://doi.org/10.1007/BF03345299

Kjaer, M., \& Dela, F. (1996). Endocrine Responses To Exercise. In: Exercise and Immune Function, Edited By L. Hoffman-Goetz. Boca Raton, Fl: Crc press. 1-20. https://books.google.com.tr/books

Kraemer, R. R., Kilgore, J. L., Kraemer, G. R., \& Castracane, V. D. (1992). Growth hormone, IGF-I, and testosterone responses to resistive exercise. Medicine \& Science in Sports \& Exercise, 24(12), 1346-1352. https://doi.org/10.1249/00005768-199212000-00007

Kraemer, W. J., \& Ratamess, N. A. (2005). Hormonal responses and adaptations to resistance exercise and training. Sports Medicine, 35(4), 339-361. https://doi.org/10.2165/00007256-200535040-00004

Mena, P., Maynar, M., \& Campillo, J. E. (1996). Changes in plasma enzyme activities in professional racing cyclists. British Journal of Sports Medicine, 30, 122-124. https://www.ncbi.nlm.nih.gov/pubmed/8799595

Morris, J. G., Nevill, M. E., \& Williams, C. (2004). Physiological and metabolic responses of female games and endurance athletes to prolonged, intermittent, high-intensity running at 30 degrees and 16 degrees $\mathrm{C}$ ambient temperatures. European Journal of Applied Physiology, 93, 159-166.

https://www.ncbi.nlm.nih.gov/pubmed/10552271

Nathwani, R. A., Pais, S., Reynolds, T. B., \& Kaplowitz, N. (2005). Serum alanine aminotransferase in skeletal muscle diseases. Hepatology, 41(2), 380-382. https://doi.org/10.1002/hep.20548

Ömer, K. (2018). Elit Güreşçilerde Antrenmanın Hipofiz Bezi Hormonları ve Karaciğer Enzimleri Üzerine Etkisi. Nobel Publishing House, $1^{\text {st }}$ Edition, 50. Ankara. 2018. https://www.nobelyayin.com/detay.asp?u=14721 
Paolisso, G., et al. (1997). Serum levels of insulin-like growth factor-I (IGF-I) and IGF-binding protein-3 in healthy centenarians: relationship with plasma leptin and lipid concentrations, insulin action, and cognitive function. The Journal of Clinical Endocrinology \& Metabolism, 82(7), 2204-2209. https://doi.org/10.1210/jcem.82.7.4087

Pollock, M. L., Gaesser, G. A., \& Butcher, J. D. (1998). The recommended quantity and quality of exercise for developing and maintaining cardiorespiratory and muscular fitness, and flexibility in healthy adults. Med Sci Sports Exerc., 30, 975-991. https://doi.org/10.1097/00005768-199806000-00032

Rosmarın, M. N., Beard, M. J., \& Robbins, S. W. (1993). Serum enzyme activities in individuals with different levels of physical fitness. J Sports Med Physical Fitness, 33, 252-257. https://www.ncbi.nlm.nih.gov/pubmed/8107477

Sinan Şamil Şam Neden Öldü, https://24timenews.com/sinan-samil-sam-neden-oldu/ 02.01.2019.

Tanriverdi, F., Unluhizarci, K., Coksevim, B., Selcuklu, A., Casanueva, F. F., \& Kelestimur, F. (2007). Kickboxing sport as a new cause of traumatic brain injury-mediated hypopituitarism. Clinical endocrinology, 66(3), 360-366. https://doi.org/10.1111/j.1365-2265.2006.02737.x

Tirabassı, N. J., Lucianne, O., \& Morteza, K. (2018). Variation of Traditional Biomarkers of Liver Injury After an Ultramarathon at Altitude. Sports health, 10(4), 361-365. https://doi.org/10.1177/1941738118764870

Zazryn, T. R., Finch, C. F., \& McCrory, P. A. (2003). 16 year study of injuries to professional kick boxers in the state of Victoria. Australia. Br J Sports Med., 37, 448-451. https://doi.org/10.1136/bjsm.37.5.448

\section{Copyrights}

Copyright for this article is retained by the author(s), with first publication rights granted to the journal.

This is an open-access article distributed under the terms and conditions of the Creative Commons Attribution license which permits unrestricted use, distribution, and reproduction in any medium, provided the original work is properly cited. 